\title{
Storying unstoried experience in therapeutic practice
}

\author{
Michael Guilfoyle
}

\begin{abstract}
Sometimes life events resist storying. Although their conversion into narrative form is often recommended as a therapeutic strategy, particularly in the case of trauma, this can be a difficult and complex process. Sometimes emerging stories are associated more with therapist than client knowledges, and therefore may not be experientially resonant, and some clients' narrative habits may predispose to problem-saturated stories and negative identity conclusions. This article uses a case study to explore the notion of unstoried experience, and the ways in which it can inhibit a sense of personal agency. I propose a constitutive witnessing practice, conceived as a constructive and generative rather than objectiveobservational practice, as a vehicle for the cultivation of ethically infused, but client-led storying activity.
\end{abstract}

In narrative therapy, we think about identity and experience as storied phenomena. However, we are not always experientially situated in stories, or in the discursive formations that organize them (Guilfoyle, 2016). Experience and story are not the same thing (Bakhtin, 1993; Bell, 1990). This becomes obvious when we have experiences so powerful that they eject us from the stories of our lives, overwhelming our narratives' capacities to contain or organize experience, leaving us lost and bewildered, without the reference points and guidance stories usually provide. Some experiences of trauma, assault, sexual abuse, and grief-and also of beauty and wonder-not only fragment the stories we use to construct experience but also defy accommodation within culturally available narratives and categories. They show us that narratives can only go so far in framing and guiding us through life's challenges. Some recommend the telling of stories in the face of troubling experiences (e.g., Crossley, 2000), but what are we to do when available stories do not resonate. when a good-enough story cannot be found?

This article addresses this question. I begin with a case study, before discussing the notion of unstoried experience. I then examine the possible contribution of constitutive witnessing, conceived here as a generative rather than objective-observational practice, to the cultivation of storying activity. 


\section{Case example: Kyle}

I met with Kyle, ${ }^{1}$ a 30 -year-old artist with a history of depression, anxiety, and suicidal thoughts. He struck me as an intelligent and articulate man who spoke openly and freely. So I felt comfortable asking what I thought was an ordinary question: "Is there something happening that might have contributed to these feelings?" Kyle fell quiet but nodded. When I asked if he could tell me what it was, he looked down at the floor, clearly uncomfortable. I said he did not have to answer my question, but he quickly said, "No. It's okay."

I reflected that this was "something that's very hard to talk about," to which he showed no visible response. So I asked the next question that occurred to me: "Does it involve another person?" His distress immediately increased: His eyes widened, and he had difficulty breathing and speaking. I poured him some water and suggested we take a break. He calmed after a minute and then, to my surprise, said, "No, I want to get on with it." So I said I assumed there was "another person," and again his breathing became ragged, but he was able to nod. "Who is it?" I asked as gently as I could. Kyle broke down, sobbing uncontrollably. He could not tell me.

Our conversation proceeded with difficulty, but Kyle wanted to convey the gist of what he was going through before our meeting ended. He later said that if he hadn't done so, he might not have come back for a second session. Eventually, I pieced together an understanding of what was happening: His church minister, a friend of Kyle's parents, had been sexually abusing Kyle since he was a child, and these attacks had become physically violent as Kyle got older, leading to numerous injuries. Whereas in these few short lines I can provide the basic outlines of a story of his situation, Kyle was not able to do so. This articulate man was not able to find words, not because he was too embarrassed or humiliated (although he felt these things), but because he had no words, concepts, or descriptions to offer. I had to piece together a "story" from the various responses he gave to my questions. I tried to guess what his posture and facial expressions said about what stung and what felt okay. I had to speculate the meaning of his eyes opening wide or closing tight, of his averted gaze, of his tears. His breathing patterns gave me clues about whether I had said something that hit too close to home. And I took guidance from nods and one-word answers.

Kyle did not tell me a story, because he had no coherent story to tell. He could only offer numerous clues through which I could begin to form some kind of narrative. The story I tell, at this point, is one that $I$ constructed. In later sessions, Kyle told me he could not possibly have told me about these experiences, because they were "jumbled ... like porridge in (his) brain;" they lacked "phenomenological coherence" (Neimeyer, Herrero, \& Botella, 2006, p. 132, italics in the original). They led him to lose track of time, leaving him unable to sequence events or understand who was doing what to whom, who was at fault, if anyone, and what his options were. He did not tell a "story" of what was happening, but I was privileged to be the first to be allowed to "know" something of what was going on. 


\section{The challenges of storying trauma}

Kyle's difficulty in storying his experience is not so unusual. Although the typical human response to traumatic experience is to tell stories (e.g., Crossley, 2000), our storying abilities can be disrupted by traumatic or life-threatening events. In his studies on chronic illness, Frank (1995) noted that sometimes people become "narrative wrecks," able to tell only "chaos stories" (p. 61). For Frank, the chaos story is not a narrative but an "anti-narrative," reflecting a chaos that can be "lived" but not told (p. 98). Similarly, Caruth (1995b) argued that the "unexpectedness or horror" of trauma means it "cannot be placed within the schemes of prior knowledge" (p. 153). It cannot be "assimilated" (Neimeyer et al., 2006). Trauma disrupts a person's capacity to narrate experience in a coherent way (Crossley, 2000; Neimeyer et al., 2006; Sewell \& Williams, 2002), and the traumatic event might only be recalled, as in Kyle's situation, as "unassimilated scraps of overwhelming experiences" (van der Kolk \& van der Hart, 1995, p. 176). Certain life events outstrip our stories, rendering them powerless to contain, organize, or give direction to experience. In such circumstances, the person is left with an unshaped, unstoried experience.

The storying of unstoried experience is no simple task. Sometimes the stories seized upon to frame an experience emerge from already "dominant," problem-saturated personal narratives (Neimeyer et al., 2006, p. 132), leaving the person with a heightened sense of failure, badness, or vulnerability (Foa \& Rothbaum, 1998; Kaminer, 2006). Although therapy can no doubt be helpful in promoting more helpful stories than this, it is also worth noting that storying can sometimes do an injustice to the experience. In his reflections on the Holocaust, Lanzmann (1995) declared, "There is an absolute obscenity in the very project of understanding" (p. 294). Speaking of his video documentary on the topic, Lanzmann stated, "Not to understand was my iron law during all the eleven years of the production of Shoah. I had clung to this refusal of understanding as the only possible ethical ... attitude" (Lanzmann, 1995, p. 294). Henry (2010) and Caruth (1995b) similarly commented on the impossibility of storying certain traumatic experiences. The story's agenda of comprehensibility comes into conflict with the experience's incomprehensibility.

These concerns about the "obscenity" or impossibility of understanding in certain circumstances speak to a particular danger of therapeutic practice: Meaning creation can distort and violate the person's traumatic experience. Our own therapeutic attempts to build a story around the person's experience-whether in the form of a diagnosis, formulation, or interpretation, or even the narrative therapist's quest to name or externalize the problemcan reduce the experience, rendering it knowable but deformed. Those of us who prioritize constructivist and narrative metaphors, who privilege the search for meanings and stories, should be cautious in this respect. However, this does not mean we have nothing to do. In order to reflect on our options in this regard, it may be useful to reflect on the notion of unstoried experience.

\section{Unstoried experience}

An unstoried experience is one that does not find resonance in-it does not connect dialogically with-the person's available stories and subject positions. Consequently, such 
experience has no access to the agentive pathways stories provide. The experience may tear a hole in the person's universe of meaning, leaving no positive narrative trace but only a "void" (Caruth, 1995a, p. 8) in which the person becomes trapped, cut off from his or her narrative "dispositions" (Frank, 2010, p. 52) and "library" (p. 54) of stories and positions. The stories to which the person has access can now be entertained only superficially, without any real identification.

Implicit in this argument is the idea that stories do things for us, and that unstoried experiences leave us cut off from these functions. Perhaps most significantly, narratives lend persons a sense of agency. This arises in a number of ways:

1. Stories give us "critical distance" from life experience (Frank, 1998, p. 207). This means that even when immersed in an experience, we do not have to fully identify with it or allow it to unduly shape our sense of who we are or could become. Stories give us the distance we need to witness ourselves, to adopt a third-person perspective on our own experiences (Amir, 2012). This reflexive capacity allows us to "play a part in choosing what (stories) to let guide us and in what contexts" (Zimmerman \& Dickerson, 1996, p. 93). The experience-story gap thereby contributes to a sense of personal agency (Oliver, 2003).

2. Stories "make present" experience, bringing it back to us (Schiff, 2012, p. 33). But they inevitably change the experience in the process. According to Bakhtin (1993), experience is unique and nonrepeatable, and should not to be confused with the meanings we assign it. Similarly, Bell (1990) argued that the story has an "implicit contract" toward order, but life experience does not (p. 174; see also Crossley, 2000). In other words, a narrative cannot represent experience in a neutral, objective way but, instead, captures, shapes, reduces, categorizes, and codifies it in its own terms. In so doing, it generates options for how we should orient to, feel about, and respond to the experience.

3. Stories give us our identities (Freedman \& Combs, 1996; White, 1993), providing us with subject positions that guide us on who we "are" or "should be" in this or that situation (Davies \& Harré, 1990; Winslade, 2005). The storied nature of identity contributes to a person's sense of agency in various ways. Although the kind of agency one is afforded may depend on how one is positioned in the story (e.g., as a perpetrator, victim, bystander, or helper), in principle the story provides its characters with a place from which to evaluate and act on their worlds. In such ways, narratives provide persons, even those in disempowered positions, with particular vantage points from which to negotiate social forces and power dynamics (Veyne, 2010).

4. Stories situate us in relation to others, guiding us on such questions as who we are to each other, and how we should act in this or that relationship. Narrative positions are always relational (Cobb, 2013) and thereby help orient us to the relational and contextual worlds of which we are a part. 
Unstoried experience does not refer here to a simple lack of words. If we consider some of these key functions of narrative, it becomes clear that a person can use words, but without enjoying the guidance, orientation, and agency pathways that stories provide. One of the key challenges arising from the narrative disruptions associated with traumatic or life threatening events is not merely that they rob the person of words, it is that they compromise the person's ability to use stories to enable a sense of agency.

\section{Kyle's unstoried experience}

Kyle's experiences disrupted his narrating ability in all four areas outlined above.

First, in the early stages of our work, he was unable to find critical distance from his experience. Instead, he sometimes felt overwhelmed by the abuse, even when it was not happening. Violent and confusing images could "take over" at any time. His difficulty in storying his experience perhaps contributed to his vulnerability to the invasion of violent images, and to feelings of panic, confusion, and terror. There was no story to contain these images and feelings, to lock them into narrative place. He was simply "in" the experience. As a consequence, Kyle was unable to witness his experience from a third-person perspective. This impeded his ability to evaluate his experience in a way that would have permitted some degree of agency. The only story that was (very occasionally) available to him positioned him purely as an object or victim, at the mercy of an overwhelmingly powerful (and possibly righteous) other. If one of the functions of person- experience distancing is to enable a modicum of agency, this story will not do. Here, Kyle is positioned not as an agent able to reflect back on his situation and represent it to himself in order to work out avenues for future action, but as an object whose only course of action was to be present as a usable and disposable body. There is no space for self-witnessing if avenues for intentional action, decision making, or agency are closed off.

To be sure, Kyle's sense of agency had not been totally devastated. But he sometimes referred to himself as the "living dead" and wondered about the pointlessness of life. He could access no stories through which to construct a self-witnessing position in relation to his experiences with the church minister. He was unable to guess if the courts, the church, the media, or any other person or institution would side with him. And if anyone found out, he thought he could be disowned by his family, imprisoned (a vague sense he could not articulate), or hospitalized for being "crazy." He could not imagine any persons or institutions taking the view that the minister's actions were wrong; certainly, he could not commit himself to such a view. His only relatively stable reference point, as far as I could ascertain, was the story of the minister as the respectable other, making use of an object (i.e., Kyle himself) that had no intrinsic rights of its own. Of course, other narrative possibilities arose in our early conversations, including the fact that Kyle had sought out therapy, guiltily wanted the minister to "disappear," and took other steps to try to improve his life. At least theoretically, such nascent stories have the potential to promote a range of subject positions, relational possibilities, and decisions that might lead Kyle to a preferred life. But for many months Kyle could not pursue such storylines or identify with them in an experiential way. 
Second, Kyle could not "make present" the experience in codified, manageable form. Neither in his account nor in his internal world was there a discernible "implicit contract" toward order (Bell, 1990, p. 174). He described the experience, and his attempts to make sense of it, not in terms of the structure and texture of an ordering narrative, but as "porridge." In later sessions, when a degree of self-witnessing became possible, he commented on the "jumble" of "chaotic" thoughts, which were incapable of offering him advice. A story cannot be a useful "companion," to borrow Frank's (2010, p. 68) term, if it consists only in a mass of fragmented confusion.

One of the advantages of storying experience is that it permits the discernment of distinctions that can be used to guide action: between self and other, between self and experience, and so on. But Kyle was unable to make clear distinctions between himself and the church minister on several crucial matters that, had they been present and stable, might have allowed an organizing story to emerge, replete with guidance on the respective parties' duties or rights (Davies \& Harré, 1990). For example, with reference to the minister's attacks, Kyle could not work out who did what and when, he was not sure it made sense to talk about someone being "guilty" or "innocent," he could not judge what counted as "good" or "bad" behavior, and he did not know if the ideas of "perpetrator" and "victim" were relevant. He knew these words, but as they did not resonate with his sense of chaos they seemed unsuitable as vehicles to bring his experience back to him.

This brings us to the third point: the identity-lending property of stories. Without such wordsvictim, perpetrator, innocent, guilty, and son on-Kyle was not able to work out who was who in the interaction. He knew the minister was "doing something" Kyle did not like. But he could not put this "something" into words, not even to himself. All he had, he said, were fragmented images, "shots of pain," and "mental porridge." Without meaningful words to organize the experience, he had no sense of how to orient to the other or to the world, or what his rights (or those of the minister) might be. In short, Kyle could find no resonant narrative through which to constitute himself as a subject, as a particular kind of person in this interaction. Indeed, so lacking was this narrative that Kyle said he was more "object" than "person." Even the category of "personhood" could not stand as a resonant theme for his sense of himself and his relationship to the world. The fact that the minister had singled him out for this treatment seemed to signal some core truth about himself: He was not a human being in the way that, he guessed, the rest of us were.

And then, finally, if stories give us a way to relate to the world, what is Kyle to do in his relationships, not only with the church minister but also with others who could offer some kind of help? It is notable in this regard that Kyle sometimes had fantasies of the minister "going away." When I asked if he meant "wishing him dead, or wishing he would move somewhere far away?" he insisted he meant the latter. In Kyle's view, a death wish was an intolerably unfair and "wrong" thing to direct at "someone I should try to respect." The story Kyle was using in these moments may well have created something of map for his own identity and self-other relationship: himself as an object, perhaps, and the minister as a righteous, respected, respect-worthy figure of authority. There are indeed narrative elements here. But, 
of course, there is a grave difficulty with this story, and it does not do what we need stories to do for us. Instead, it leaves Kyle positioned without any possibility for agentive action and disqualifies his preferences. If stories help orient us to ourselves and our social partners, we should note that even "orienting" is an active, agentive, choice-filled action. But Kyle was left with no way to intentionally do so. This story left him with no role to play as an active agent. He could only obey, as a docile and usable body, and absorb the assaults and spoiled identities that came his way. In Bakhtin's (1984) terms, this is a "finalizing," "degrading and deadening" story (p. 59) that fails to do what we need stories to do for us.

\section{Therapeutic witnessing: a route to storying activity}

Being a narrative practitioner, I made several attempts to facilitate a storying of Kyle's seemingly more hopeful actions and intentions, which might work against his sense of hopelessness, domination, and mental "porridge." But these failed. He could not story the experience, never mind thicken his understanding to allow for the emergence of unique outcomes. So, in a move that left me feeling useless at first, I tried to honor his confusion and bewilderment, and support him by "just listening." As Frank (1998, p. 197) noted, even the chaos narrative "deserves to be honoured in its time of telling" (p. 206) and should not be prematurely pushed in the direction of order and meaning. Kyle later referred to my listening as a "witnessing" of his experience. I reflected on this term and decided to use it in our conversations. It occurred to me that witnessing is more a constitutive than an observational sort of practice. Indeed, I came to think of it as an inherently storying sort of activity, which contributed to the building of a narrative that permitted Kyle to gain some distance from the experience, to witness himself and his place within it, to re-represent aspects of the experience to himself and to me, and to step toward finding a position or identity for himself that had an important relational component. Below, I describe the four orientations I found useful in this witnessing practice.

\section{Look, Say What I See, and Don't Look Away}

What I found most challenging in my work with Kyle was my initial feeling of powerlessness in relation to the horror I saw unfolding before me. I wanted him to contact the authorities, and I spent hours in peer supervision reflecting on my role in this. Kyle saw reporting the abuse as a dangerous course of action. He feared the minister's violence would escalate. He feared he would be hospitalized for being "crazy" and disowned by his family, who "looked up to" the minister. He feared the minister's "cleverness" would trump his own "stupidity." And, in any case, there was "no proof." Even if he decided to speak up, he knew he would never be able to tell a coherent story to the police. So I struggled for some time with my own sense of horror and powerlessness. But my struggle translated into pressure on Kyle. He sometimes apologized for disappointing me, for being "a difficult client" who was "too weak" to take the appropriate action. My hope that Kyle would dramatically address his situation, once and for all, was not only unhelpful but also dishonoring of his experience and of his hopes for the therapeutic relationship. He had not asked me to "fix" the problem.

So, in the spirit of Frank's (1998) "just listening," I resolved to look, to say what I saw, and to not look away. This seemed closer to Kyle's hopes for our interaction. He wanted someone, for 
the first time, to see, not to look away, and to reflect back what he or she saw-without taking over. I realized that my wish for some grand intervention was, at least in part, an escape, a flight to an imaginary haven, far removed from the chaos, pain, and violence in which Kyle was immersed. Frank (1998) warned that each listener has preferences for what kind of story he or she wants to hear, and I had to be careful that my narrative therapeutic orientation did not lead me to overly privilege unique outcomes and hopeful actions.

And there was another kind of looking away. At one point, feeling enraged when I learned the minister had used a lit cigarette to burn Kyle, I began to wonder if Kyle was exaggerating or manipulating me for sympathy. Could Kyle be burning himself and then blaming an imaginary persecutor? I realized how easy it was to look away, with a pathologizing diagnosis. Indeed, witnesses may be tempted to withdraw from horror in any number of ways (Langer, 1991). I had averted my gaze because I found it hard to bear what I was seeing. Kyle noticed this, and at one point commented that I had "left the building." I was stung by this comment, but he was right. So I resolved to endure my sense of powerlessness, and to return to stand alongside him, looking with him at the overwhelming fragments of experience he was sharing with me.

Although our looking was inevitably different-shaped in part by our own distinct histories, values, hopes, and contexts-Kyle spoke later about a feeling of being "less alone" when we sat together. He once told me that my looking helped him to look:

I knew something was very bad, but I didn't know what it was. But then it's as if you saw what it was and you told me, "Hey, you've been stabbed!" So I could look at the stab wound. I could see it! I could see how deep it was and how long it was and where it was. ... It wasn't just something bad, it was more specific. It was a stabbing.

He had not literally been stabbed, but my looking led him to a metaphor that fit for him. The witnessing of his injury allowed him to determine, at least metaphorically, what kind of injury it was (see Neimeyer, Burke, Mackay, \& van Dyke Stringer [2010] for a discussion of the usefulness of metaphorical language in grief counseling).

My suggestion is that the therapeutic witness look into the horrors of the other's experience and say what he or she sees, but without trying to "recognize" the person or the experience in familiar storylines and categories of meaning. In this way, we resist the temptation to soothe ourselves with our own stories of the person, crafted in terms of our own favored theories.

\section{Historicize and Legitimize the Person's Experience}

In his letters to people who had endured horrific life experiences, narrative therapist David Epston sometimes conveyed an understanding that the person's negative sense of self is not indicative of failure but a legitimate consequence of what the person has been through. In one example, he wrote a letter to Rose, a young woman who had been abused in childhood by 
her father and who now felt she lacked a "base" in life (Epston, White, \& Murray, 1992). Consider part of Epston's response:

I can see how such a history could have left you the legacy you described-a sense of not seeming "to have a base." How could you under the circumstances of your growing up when your home-most people's base-was the site of your father's attempt at disappearing you? No wonder you are currently finding life difficult and have mixed feelings about trusting relationships with men. I consider this inevitable under the circumstances. (Epston et al., 1992, p. 103; emphasis added)

Epston constructed Rose's difficulties-here, the lack of a "base"-as an almost inevitable result of her life circumstances. Her difficulties were considered already legitimate, recognizably human, even if not fully understood or storied. In such ways, a person-even one who considers herself bad, strange, deviant, or crazy-is situated alongside us, as a fellow member of the club of human beings. Weingarten (2003) saw such an appreciation of our "common humanity" as lying at the heart of "compassionate witnessing" (p. 22).

This approach may resemble the strategy of "normalizing" a person's response to trauma (e.g., Das-Brailsford, 2007), but there are problems with this term. First, it privileges the notion of societal norms and situates clients' responses among them. For example, Figley and Kiser (2013) recommended telling traumatized families that their responses are "common and predictable," and that "others describe similar issues" (pp. 91-92). This may be reassuring, but it reproduces the culture of normalizing judgment (Foucault, 1977; White, 2007): It implies that certain other responses are "abnormal," and it reduces the complexity and uniqueness of each person's experience to some cultural standard. I do not see Epston's words as "normalizing." He did not suggest that Rose's response is "common" or "similar to that of others." Instead, he gave an account of why it may be inevitable in her specific situation, given her specific history. Furthermore, in contrast to the normalizing technique, Epston did not rely on a distinction between "normal" and "abnormal" responses, such as we see in debates about the normality or otherwise of responses conceptualized as posttraumatic stress disorder (Shalev, 1996). Instead of normalizing Rose's responses, Epston historicized and personalized them. He constructed them as recognizably human. Indeed, for Falzon (1993), it is precisely our vulnerability to being subject of and to our histories and prevailing discourses that makes us human subjects.

Considering all of these factors, it might be useful for the therapist to become attuned to (a) the personal historical conditions that might promote the response that is witnessed, and (b) the ways in which the person's responses are always already suggestive of his or her fellowship in the community of human beings.

When Kyle apologized for not being able to put things into words, I responded with comments informed by my commitment to the idea that he is a fellow human being, and that we human beings do not always know how to story experiences that traumatize us: "No wonder you can't tell this story ... it seems pretty much untellable!" Or, "It sounds like 
an utterly mad, crazy thing that's going on. I don't know if you could really put it into words." Such comments mean to suggest that we all have experiences for which words cannot do justice, for which our histories have not prepared us. If unstoried experience threatens to strip persons of their humanity, the witness's acknowledgment that this unstory-ability is legitimate and perhaps inevitable ("No wonder you can't tell this story"), paradoxically, positions the person as recognizably human. In these circumstances, it is not Kyle's storying but, precisely, his inability to tell stories that makes him (something like) "one of us." Such inclusion can itself serve as the beginning of storying.

When Kyle said he was "useless" and "not brave enough" to fend off the minister or do more to resolve his situation, I tried to legitimize these feelings by offering my view on their historically constituted nature:

No wonder you can't fend him off. You've been trained through much of your life, at home, at school, in church, to look up to the minister as a representative of God Himself, to accept that authority. I mean, honestly, how is a person in your position supposed to act under these circumstances?

Once again, such legitimizing statements are constitutive rather than observational. Witnessing is not an impartial act. It inevitably alludes to directions in which subsequent meaning making might proceed. If Kyle positions himself as an object or as useless, my own reflections reposition him as a person who, like the rest of us, is bound by the situations and contexts within which he lives, and who does not always have as much choice as he would like in finding alternative ways to act and think.

Not only is Kyle subject to power, as we all are (Falzon, 1993), but the witness affirms the horror and overwhelming nature of this particular brand of power. In these moments he is positioned not as the failed being he thinks he is, but as just another human being subject to the vicissitudes of interpersonal power relations. For the witness, Kyle's sense of powerlessness is not simply a feature of his personality or identity; it is not read or interpreted in that way. But the witness who legitimizes the person's experience thereby immediately invites an alternative story: My legitimizing look positions Kyle as a fellow human being, with the capacity to suffer and be overwhelmed. This was extremely important in his situation, given his doubt that he even counted as a "person." Now, his inability to tell a coherent story is read as proof of his personhood. Sometimes, then, it is precisely the incomprehensibility, the unstory-ability of experience (e.g., trauma, the Holocaust, the horrors of Apartheid) that has the potential to reveal our humanity, and even to bind us. If there is a basis for a "story" here, it might concern the person's full status as a person, as a legitimate member of the human community.

\section{Stand in Solidarity with the Person}

The therapeutic witness cannot be a neutral observer of events. What is witnessed cannot be known in an objective sense. Both client and therapist are unavoidably shaped by circulating discourses and practices, and are caught up in societal power dynamics (Falzon, 
1993). Thus, a therapist's reflection ("What I see or hear is ...") cannot describe some reality gleaned from a God's-eye view, but is inevitably shaped by social power and discursive operations. But if we, and our actions, are part of the broader societal play of power dynamics, then we should consider our positions with respect to these power arrangements: What is our stance on abuse, or on this abuse? What is our position on people who have faced natural disasters, death, assault, marginalization, forced removal from their homes? Are we able to communicate our positions on such matters to clients so affected? Indeed, many trauma therapists have moved away from conceiving their role as "neutral" toward one of solidarity (Kaminer, 2006).

This stance matters: The therapist's attitude feeds into the power dynamics of the client's life. We cannot avoid communicating something-whether by judging, sympathizing, or intellectualizing-thereby suggesting one kind of story rather than another. Our stance as witnesses may even contribute inadvertently to the way a client acts into his or her circumstances. For example, the abused client who feels judged by the therapist may blame him- or herself; but if that client feels supported, he or she may be emboldened to make changes. The therapist's attitude can impact the client's sense of legitimacy, entitlement, and acting potential within the trauma situation and its aftermath. Such is the enormity of our responsibility. And so we must ask: Do we support, judge, minimize, respect, or honor the client? Do we honor the client's inability to tell a story about his or her distress? And when the client does begin to tell a story, do we believe and respect that telling and those words, or do we use our knowledge to become therapeutically suspicious, to categorize the account into some preexisting theoretical system? Do we think of our client as a victim, a survivor, or a personality disordered manipulator?

Our position is important. Witnessing calls on us not to act as knowing experts but as witnesses equipped with and engaged by our own ethical subjectivity (Foucault, 1992, 2001)-by our sense of what is important, what is good, what should be supported and what opposed. In Kyle's case, an incident occurred with just such an ethical witness, which would eventually contribute to his ability to story his experience. He told me that I was the first person to "really see" what was going on. I asked if anyone else had come close to "really seeing," and he recalled an incident from many years earlier, when he was a university student. A lecturer noticed that Kyle's face was bruised, and asked if he was okay. Kyle broke down in tears, but could not speak. The man put his hand on Kyle's shoulder and said, "Oh no. It's ghastly. I'm so sorry." Kyle did not know what this man had guessed was happening, but he did not push the matter further. Instead, the lecturer said he was available to talk if Kyle ever wanted to. Kyle never took up the offer, but he interpreted the lecturer's response as a kind of solidarity with him. "It felt like he was with me." Someone had detected that something "ghastly" was happening, that it was not Kyle's fault, and had expressed care. Kyle contrasted this with the comment of another person, who simply said, "Sort out your life!" Kyle realized that both his lecturer and I were "on his side," standing in opposition to the abuse he was suffering. In this way, the witness's activities open up an ethical landscape, implicitly (and sometimes explicitly) suggesting that some things are important, good, and right, whereas others are bad or wrong. The client is effectively invited to engage with this ethical landscape, to find a place 
within it, refine its borders and features, refute it perhaps, or to use it as a stimulus to explore alternative ethical territories.

As witnesses, it is important that we recognize that our own attitudes to what we hear will impact the client's orientation to the experiences he or she is trying to share, and to his or her own position in relation to them. However, sometimes the therapist's orientation will waver. This can be an opportunity for self-reflection on the part of the therapist, as well as for some important dialogues between client and therapist. For example, at one point in our work together, I felt impatient, wishing that Kyle would take practical steps to escape the situation completely. I imagined confronting the church minister myself, or calling the police to have him arrested. I did not say these things out loud, but my hopes for dramatic action came through in my questions. (For example, "Do you ever think about taking more extreme action?" "What's the down side of going to the police?") One of the effects of these fantasies is that they left Kyle feeling alone and a failure. He noticed my shift and said he was worried he had disappointed me by "being too passive." He reminded me of the many significant steps he had already taken, leaving me to reflect on my desire for a particular sort of action. Following this self-reflection, I acknowledged to Kyle the urge I sometimes felt to "fix things." In conversation, I wondered whether these internal pressures signaled a difficulty I had in tolerating the horror of his experience, leading me to disconnect at times. This conversation allowed me to return to stand in solidarity with him, alongside him, rather than trying to lead from the front.

The solidarity of the witness is not merely an act of standing beside the person, but functions also to invite an ethical landscape-comprising suggestions for what is important, what is right or wrong, what should be done or not done-and thereby to nurture the story-telling process. Witnessing promotes the production of meaning in situations where meaning is otherwise fragmented or seemingly absent. Kyle's recognition that there were two different people (the university lecturer and myself) standing by him, who felt his experience to be "ghastly" and "horrific," served as a platform for a particular kind of story to emerge, in line with the ethical landscapes communicated by these witnesses.

Of course, the witnessing could have proceeded differently. A witness could have noticed Kyle's "weakness" or his "failure" to act-Kyle was ready to identify with such descriptionswhich would have led to different stories and different ethical territories. But in this case, the idiosyncrasies of the particular witnesses (i.e., Kyle's lecturer and myself) suggested and helped crystallize the following elements of meaning: Kyle was a person reacting in recognizably human ways; he was being treated very badly, and this was unfair; the treatment was beyond what a person should be expected to endure; he deserved care rather than judgment; and there was a perpetrator doing very bad things. These elements of meaning pervaded much of my orientation to Kyle, and were embodied in just a few seconds by his university lecturer. Perhaps we served as gentle "sponsors" of the emerging discourse (Neimeyer et al., 2010). As witnesses, we offered building blocks for a particular kind of story to emerge, associated with a particular ethical framework. It is a story that Kyle would soon begin to tell. 


\section{Find Personal Resonance While Acknowledging Difference}

I tried to stay close to Kyle's experience, but I also felt it important to occasionally remind us both that this was not my situation or story, that I did not have the lived knowledge he had, and that many of my responses emanated from reflections on what I could only imagine. Nevertheless, while acknowledging the gap between his experience and mine, I sought elements of personal resonance (White, 2007).

The primary purpose of finding personal resonance is not to convey understanding or promote solidarity, but to locate the person's experiences within a profoundly social and hence meaning-producing space. The sharing of aspects of the therapist's story-tentatively, while acknowledging difference-invites the client to consider his or her experience as somehow relatable, as recognizably human, even if not fully comprehensible. The expression of personal resonance is a constitutive act insofar as it positions the client's experience as somehow of this world, part of the human experience, and relevant in particular ways to particular persons. Furthermore, it allows the person to contrast the therapist's personal account with his or her own situation, to find intersections and points of disconnection. Words, concepts, and statements can be tested out for fit, and may be taken up, modified, rejected, or set aside for later consideration. So if the person who is unable to story an experience seems energized or intrigued by my own story, I might ask, "Can you say what it is about this story that fits for you?" Or, if I realize that my story is not relevant, I might say, "I have a sense that what I've said doesn't really speak to the heart of things. What do you think?" Such incongruity is an opportunity to seek clarification, enabling the person to further story his or her otherwise chaotic experience. The offering of personal resonances thereby contributes to meaning making, in which stories are born, consolidated, and eventually thickened. For example, well into our work together Kyle was telling me about his sense of powerlessness. He wondered if he was making any sense, and apologized for being confused. I said, "In my mind it's making sense, but ... let me tell you an experience I had, and see if that relates in some way to what you're talking about."

I told him about the unexpected, sudden death of my brother, while making it clear that I knew this was a very different situation. "While you were talking, I had an image of myself trying to help my brother (I then told him about the circumstances of his death) ... and it took me a while to realize that I couldn't. I had no say. That was such a hard thing to accept." I reiterated that this was very different from his experience, but that his words nevertheless reminded me of my own powerlessness in dealing with a traumatic event: "It's different, but your sense of powerlessness touched me, and you apologized and thought you weren't making sense. So I wanted to say, 'I think I hear you,' and to share my own experience of the devastation that can come from that feeling of having no control, no power over something that's so important."

Kyle expressed his condolences and thanked me for sharing my experience. In the next session he told me of his shock that someone "like" me could feel powerless too. He told me, "It helped to think about it. You were listening, and I felt less alone, like maybe I'm not being so 
pathetic." The sharing of my experience helped Kyle to feel part of the human world from which he'd felt excluded.

\section{The emergence of stories}

Such witnessing practices contribute to the emergence of storying activity. A series of distinctions begins to emerge, allowing the person to move from the experience of chaos or fragmentation ("mental porridge") to having a sense of discernable meaning-pieces interacting with each other in particular ways, in a particular context. The voice and presence of the witness inevitably play a role in this movement, from chaos to order, in the first instance by treating the experience as a relatable one. This does not mean it is "understandable." I mean only that I recognize the person's experience as a human one, one that could be shared by any number of people caught up in that particular life; in those power dynamics; in that society, community, or family; with that history.

This therapeutic witnessing process seemed to facilitate Kyle's storytelling. First, he was moved that his lecturer and I saw "ghastliness" and "horror" in his situation. This may have contributed to a modicum of critical distance from the experience itself. These reflections permitted a move away from a purely chaotic, undifferentiated, porridge-like experience, toward one with certain qualities that could therefore be evaluated. It may seem obvious to many that the experience was horrific, but this was not at all evident to Kyle, who was shocked to hear others express this sentiment. Kyle's realization that his experience could be evaluated in this way contributed to its storying. He quickly followed up by saying the church minister was acting in a "bad way." His adoption of this position was significant. Kyle was previously loath to speak of the minister in critical terms. This miniscule meaning fragment-"bad" behavior-flowered over the next sessions, to the point at which Kyle began to find symbols to represent the minister. He found it difficult to speak of the man by name, preferring "him" or "he," without judgment or evaluation. Knowing Kyle had a fondness for comic books, I asked if there was some figure who reminded him of the minister. He told me that "Count Vertigo" (a villain in the DC Comics Universe) came to mind-a villain who tinkered with people's minds and confused them. This symbolic discourse opened up our conversations considerably, and he told me he had been "mind controlled" by "Count Vertigo," who convinced him to take the blame for what was happening.

To develop this nascent story further, without prematurely moving to more "literal" talk (Neimeyer, 2012, p. 57), I asked Kyle who he might be in relation to Count Vertigo. He said he admired the "Green Arrow" (a DC Comics Universe hero), who had many tricks to deal with criminals and masterminds. This led to speculation on how Kyle might have tricked the church minister, and he was surprised that several examples came to mind: He sometimes slipped out through the back of the house when the minister arrived; he found legitimatesounding reasons to be away for weekends; and he moved to a different church, citing reasons of "spiritual belief," despite his parents' and the minister's protests. A great deal of stories began to emerge. 
The critical distance provided by witnessing acts seems to facilitate a narrative codification of the experience. Such codification in turn stabilizes that critical distance, allowing the person to observe, evaluate, and make decisions about his or her experience. In Kyle's situation, "mental porridge" was giving way to a kind of narrative order. Now we had a way of evaluating the experience (horrific and ghastly) as well as a growing range of characters (incorporating self, abuser, witnesses).

We have seen that one of the primary functions of stories is that they provide subject positions, in terms of which identity possibilities can be constructed. Kyle's admiration of the Green Arrow, and his distrust of Count Vertigo, assisted in this respect, allowing him to find a specific place in relation to what was happening, to figure out who he was in the situation. His initial, undifferentiated sense of himself as "a mess" was transformed through narrative activity into a more crystallized sense of having been "mind controlled," which then developed into a vision of himself as one who sought to be alert to these mechanisms, who was already counteracting them, and who was legitimately planning an escape. These stories also allowed Kyle to develop a clearer sense of his relations with others: He recognized that his witnesses were moral supporters of his quest, he could now describe the church minister in critical terms, and he demonstrated empathy for and imaginative solidarity with others who had endured and continued to endure abusive experiences. His chaotic experience began to find a kind of order, which helped orient him to a number of facets of his life; gave him a place from which to examine, evaluate, and make decisions about his experience; and even suggested courses of action in line with his newly legitimated desire to actively change his life circumstances. These were significant shifts, which enabled a level of personal agency Kyle had not experienced before.

Over time, Kyle began to work out ways to escape his abusive interaction. He applied for a scholarship to study for a Ph.D. in another country. He said he had previously thought this impossible, as the minister would never allow it. But it now emerged as a possibility through the emergence of a set of stories that legitimized his desire to escape his situationstories that initially constructed him as a victim, and then as one empowered and entitled to make decisions in line with his preferences.

\section{Conclusion}

A significant effect of storying activity is that it provides us with the distance to negotiate and reflect on our lived experiences, and to construct story-aligned and agentive courses of action. But this narrating ability can be compromised by certain life events, which are not easily assimilated into the stories in and through which we have lived our lives, or even in available societal discourses. In a sense, these overwhelming experiences can dislodge us from our stories and, in turn, from our sense of legitimate personhood. This leaves us with an important therapeutic task: fostering the resumption of storying activity. Success in this regard contributes to the restoration of a sense of personhood, to the person's resituation as a fellow human being. This needs to be done carefully in the therapeutic relationship, without undue imposition of favored theories, formulations, or diagnostic systems. This article offers the outlines of certain witnessing practices that aim to honor the person's difficulty in telling a 
coherent story and to legitimize his or her bewildered responses, but that also gently invites the person to situate him- or herself in an ethical landscape, comprising a tentative network of words, images, and values derived from the client's life, serving as a temporary island of meaning, which then becomes available for ongoing negotiation, challenging, restructuring, or development. In such a context, witnessing may serve as a route to storying activity.

\section{Acknowledgements}

I would like to thank Christoffer Haugaard for his thoughts on this project, as well as participants of the "Opening Up Possibilities Through Narrative Practice" conference (Cape Town, South Africa), whose questions and comments helped me clarify aspects of my article. This work is based on research supported by the National Research Foundation (NRF, South Africa). Any opinion, findings and conclusions or recommendations expressed in this material are those of the author, and the NRF does not accept any liability in regard thereto.

\section{Note}

1. Identifying details have been changed to protect anonymity. 


\section{References}

Amir, D. (2012). The inner witness. The International Journal of Psychoanalysis, 93, 879896. Bakhtin, M. (1984). Problems of Dostoevsky's poetics. Minneapolis, MN: University of Minnesota Press. Bakhtin, M. (1993). Toward a philosophy of the act. Austin, TX: University of Texas Press.

Bell, M. (1990). How primordial is narrative? In C. Nash (Ed.), Narrative in culture: The uses of storytelling in the sciences, philosophy, and literature (pp. 172-198). London, UK: Routledge.

Caruth, C. (1995a). Trauma and experience: Introduction. In C. Caruth (Ed.), Trauma: Explorations in memory (pp. 3-12).

Baltimore, MD: Johns Hopkins University Press.

Caruth, C. (1995b). Recapturing the past: Introduction. In C. Caruth (Ed.), Trauma: Explorations in memory (pp. 151- 157). Baltimore, MD: Johns Hopkins University Press.

Cobb, S. (2013). Speaking of violence: The politics and poetics of narrative in conflict resolution. Oxford, UK: Oxford University Press.

Crossley, M. L. (2000). Narrative psychology, trauma, and the study of self/identity. Theory \& Psychology, 10(4), 527- 546.

Das-Brailsford, P. (2007). A practical approach to trauma: Empowering interventions. London, UK: Sage.

Davies, B., \& Harré, R. (1990). Positioning: The discursive production of selves. Journal for the Theory of Social Behaviour, 20, 43-63.

Epston, D., White, M., \& Murray, K. (1992). A proposal for a re-authoring therapy: Rose's revisioning of her life and a commentary. In S. McNamee \& K. J. Gergen (Eds.), Therapy as social construction (pp. 96-115). London, UK: Sage.

Falzon, C. (1993). Foucault's human being. Thesis Eleven, 34, 1-16.

Figley, C. R., \& Kiser, L. J. (2013). Helping traumatized families. New York, NY: Routledge.

Foa, E. B., \& Rothbaum, B. O. (1998). Treating the trauma of rape: Cognitive-behavioral therapy for PTSD. New York, NY: Guilford.

Foucault, M. (1977). Discipline and punish: The birth of the prison. London, UK: Penguin.

Foucault, M. (1992). The use of pleasure: The history of sexuality (vol. 2). Harmondsworth, UK: Penguin.

Foucault, M. (2001). The hermeneutics of the subject: Lectures at the College de France, 1981-1982. Basingstoke, UK: Palgrave Macmillan.

Frank, A. (1995). The wounded storyteller: Body, illness, and ethics. Chicago, IL: University of Chicago Press.

Frank, A. (1998). Just listening: Narrative and deep illness. Families, Systems, \& Health, 16(3), 197-212.

Frank, A. (2010). Letting stories breathe: A socio-narratology. Chicago, IL: University of Chicago Press.

Freedman, S., \& Combs, J. (1996). Narrative therapy: The social construction of preferred realities. New York, NY: Norton.

Guilfoyle, M. (2016). Subject positioning: Gaps and stability in the therapeutic encounter. Journal of Constructivist Psychology, 29(2), 123-140. 
Henry, N. (2010). The impossibility of bearing witness: Wartime rape and the promise of justice. Violence against Women, 16(10), 1098-1119.

Kaminer, D. (2006). Healing processes in trauma narratives: A review. South African Journal of Psychology, 36(3), 481- 499.

Langer, L. L. (1991). Holocaust testimonies: The ruins of memory. New Haven, CT: Yale University Press.

Lanzmann, C. (1995). The obscenity of understanding: An evening with Claude Lanzmann. In C. Caruth (Ed.), Trauma: Explorations in memory (pp. 200-220). Baltimore, MD: Johns Hopkins University Press.

Neimeyer, R. (2012). Analogical listening. In R. Neimeyer (Ed.), Techniques of grief therapy: Creative practices for counseling the bereaved (pp. 55-57). New York, NY: Routledge.

Neimeyer, R., Burke, L. A., Mackay, M. M., \& van Dyke Stringer, J. G. (2010). Grief therapy and the reconstruction of meaning. Journal of Contemporary Psychotherapy, 40, 7383 .

Neimeyer, R., Herrero, O., \& Botella, L. (2006). Chaos to coherence: Psychotherapeutic integration of traumatic loss. Journal of Constructivist Psychology, 19(2), 127-145.

Oliver, K. (2003). Subjectivity and subject position: The double meaning of witnessing. Studies in Practical Philosophy, 3(2), 132-143.

Schiff, B. (2012). The function of narrative: Toward a narrative psychology of meaning. Narrative Works: Issues, Investigations, \& Interventions, 2(1), 33-47.

Sewell, K. W., \& Williams, A. M. (2002). Broken narratives: Trauma, metaconstructive gaps, and the audience of psychotherapy. Journal of Constructivist Psychology, 15, 205218.

Shalev, A. Y. (1996). Stress versus traumatic stress: From acute homeostasis reactions to chronic psychopathology. In B. van der Kolk, A. C. McFarlane, \& L. Weisaeth (Eds.), Traumatic stress: The effects of overwhelming experience on mind, body, and society (pp. 77-101). New York, NY: Guilford.

van der Kolk, B. A., \& van der Hart, O. (1995). The intrusive past: The flexibility of memory and the engraving of trauma. In C. Caruth (Ed.), Trauma: Explorations in memory (pp. 158-82). Baltimore, MD: Johns Hopkins University Press.

Veyne, P. (2010). Foucault: His thought, his character. Cambridge, UK: Polity Press.

Weingarten, K. (2003). Common shock: Witnessing violence every day-How we are harmed, how we can heal. New York, NY: Dutton.

White, M. (1993). Commentary: The histories of the present. In S. Gilligan \& R. Price (Eds.), Therapeutic conversations (pp. 121-135). New York, NY: Norton.

White, M. (2007). Maps of narrative practice. New York, NY: Norton.

Winslade, J. (2005). Utilising discursive positioning in counselling. British Journal of Guidance and Counselling, 33, 351-364.

Zimmerman, J. L., \& Dickerson, V. C. (1996). If problems talked: Narrative therapy in action. New York, NY: Guilford. 